\title{
Theoretical Territoriality Paradox for the Intellectual Property Protection in Outer Space and Its Regulatory Approach for Reconciliation
}

\author{
Zhijie Chen*
}

\begin{abstract}
The sustainable development of outer space demands the protection of intellectual property in outer space. However, it worth noting that the intellectual property international treaties have not explicitly regulated in their provisions the issue of intellectual property protection in outer space, neither the provisions of the five outer space treaties explicitly address the legal issue. One suspicious rationale resulting in this legal status is the theoretical territoriality paradox between the legal regimes of outer space and intellectual property. This article aims to unveil the theoretical territoriality paradox by comparing the two legal regimes of outer space and intellectual property. It then moves to argue that the paradox is proved to be a theoretical problem since the legal value of Article VIII of the Outer Space Treaty elaborately reconcile the theoretical paradox and practically provides a self-contained mechanism that would permit guaranteed levels of intellectual property rights protection in outer space.
\end{abstract}

\section{Keywords}

Outer Space, Intellectual Property, Territoriality Paradox, OST

* Postdoctoral Fellowship of the Faculty of Law, University of Macau. LL.M. (Univ. of Macao), MPhl. \& Ph.D.(UHK). ORCID: https://orcid.org/0000-0002-6546-7352. I thank Professor Yun Zhao from the Faculty of Law of the University of Hong Kong and Professor Rostam J. Neuwirth from the Faculty of Law of the University of Macau for offering instructive advice during my writing. All errors are my own. He may be contacted at: zhijiechen@um.edu.mo / Address: Faculty of Law, University of Macau, E32, Avenida da Universidade, Taipa, Macau, China. All the websites cited in this article were last visited on May 5, 2020. 


\section{Introduction}

The commercialization of outer space has become a distinct characteristic of space development over the past few decades. Many non-governmental entities have taken the opportunity to participate in space activities as they believe that space exploration can provide a handsome profit in return for their investment when their space projects succeed. ${ }^{1}$ Considering a potentially significant financial reward, the space industry has seemingly undergone a paradigm shift from state monopoly to private business, as well as unilateral activity to co-operational, international, and contractually-based arrangements. ${ }^{2}$ Against such changes in the regulatory environment, space investors have started to understand that intellectual property rights ("IPRs") protection is of great importance for continuing their business development, especially those activities that concern space research. While the increasing tendency towards space commercialization has increased the need for IPRs protection in outer space, the outer space treaties neither contain any provisions that directly mention IPRs, nor existing intellectual property ("IP") treaties explicitly state the application of IPRs in outer space. The absence of a solid legal basis in space law that grants IPRs to non-governmental entities may result in a dilemma for space industries, so that there is the need for legal clarification. In fact, discussions on the application of IPRs to outer space activities have been ongoing for several decades, but results from these discussions have not been satisfying. ${ }^{3}$ Legal uncertainties concerning whether the outer space treaties will admit IPRs in outer space remain till now. One of the predominant rationales that have contributed to such legal uncertainty is the theoretical territoriality paradox between the legal frameworks of outer space and IP. ${ }^{4}$

The purpose of this article is to unveil the theoretical territoriality paradox between the two different legal regimes of outer space and IP and examine how this paradox is reconciled under the existing international legal framework. This is

1 J. Logsdon, Ronald Reagan and the Space Frontier 171-92 (2019). See also R. Mitchell, Into the Final Frontier: The Expanse of Space Commercialization, 83 Mo. L. Rev. 438-42 (2018).

2 D. Irimies, Promoting Space Ventures by Creating an International Space IPR Framework, 33 Eur. Intell. Prop. Rev. 35-6 (2011). See also Y. Zhao, The Role of Bilateral and Multilateral Agreements in International Space Cooperation, 36 Space Pol'y 12-8 (2016).

3 The legal research on this topic has started since 1970s. See e.g. H. Saragovitz, The Law of Intellectual Property in Outer Space, 17 Ptc J. Res. \& Educ. 86-98 (1975); R. Abeyratne, Space Security Law 83-106 (2011); M. Cuevas, The Protection of Intellectual Property Rights in Outer Space Activities, 12 J. Intell. Prop. L. \& Prac. 714 (2017).

4 Supra note 2, at 38-42. 
mainly achieved by comprehensively unveiling the theoretical territoriality paradox. In this regard, the legal value of Article VIII of the Treaty on Principles Governing the Activities of States in the Exploration and Use of Outer Space, including the Moon and other celestial bodies ("OST") in fact elaborately reconcile the theoretical paradox and practically provides a self-contained mechanism that would permit guaranteed levels of IPRs protection in outer space. This paper is composed of five parts including Introduction and Conclusion. Part two will demonstrate the prohibited territorial sovereignty under outer space legal regime. The primary legal value of the nonappropriation principle in Article II of the OST is to preclude territorial acquisition. Part three will investigate the territoriality principle in IP law and prove that this principle has been the unchanging basis of the constantly evolving IP laws. Part four will examine the legal value and consequences of Article VIII of the OST as well as its essential impact on reconciling the theoretical territorial paradox. In this research, the author will conclude that even there is a territoriality paradox in theory, it does not necessarily mean that such theoretical conflict will bring substantive legal obstacles to the application of IPRs to space activities, including the legal harmonization of an international treaty for IP protection in outer space in the future. The territoriality paradox is a problem that appears merely in legal theory and it is well reconciled by Article VIII of the OST, which provides a self-contained mechanism that permits the existence of IPRs in outer space in legal practice. ${ }^{5}$

\section{Prohibited Territorial Sovereignty under the Space Legal Regime}

Article II of the OST states that that "outer space, including the Moon and other celestial bodies, is not subject to national appropriation by claim of sovereignty, by means of use or occupation, or by any other means." The "non-appropriation principle" in Article II represents an essential concept of space law, and indicates that any extension of state sovereignty to outer space is prohibited. Territorial sovereignty, as a component of state sovereignty, is prohibited as well. ${ }^{6}$ Therefore, outer space is a res communis omnium, something that is open for the free exploration and use by all

5 Z. Chen, The Application of Existing Intellectual Property Legal Regime to Space Activities: A Self-Contained Mechanism in The Outer Space Treaty, 50(1) Hong Kong L. J. (forthcoming 2020).

6 For the general relationship between sovereighty and territory, see generally T. BIERSTEKER, HANDBOOK OF INTERNATIONAL ReLATIONS (2002). 
states without the likelihood of appropriation. ${ }^{7}$ Considering that the acquisition of territorial sovereignty in outer space is not allowed, neither outer space nor any of its components fall under the jurisdiction of any state.

\section{A. Understanding of the Non-Appropriation Principle}

Claiming sovereignty in outer space is prohibited by Article II of the OST, which is closely related to the objects and purposes of the space law regime. Modern space law originated in the 1960s and 1970s, a period when the world was caught up in the Cold War, and those rules have not changed much. It is against such a historical context that the provision for prohibiting national appropriation was introduced to reject claims of national sovereignty in outer space. Since the beginning of space activities, many States have determined to reject any territorial claims over outer space or any of its parts and reinforce the non-appropriative nature of outer space. Article II of the OST as the best means to maintain peace in space guarantees that all humankind could benefit from space exploration and use. More than 50 years after the OST came into force, it is safe to maintain that the non-appropriation principle has been successful in allowing the safe and orderly development of space activities. ${ }^{8}$

Article II of the OST also provides that outer space is not subject to appropriation by means of use or occupation. Therefore, from a legal point of view, neither scientific nor commercial use of outer space will ever be sufficient enough to validate a claim of territorial sovereignty over outer space as a whole as well as its parts. For example, the landing of a space object on the Moon for research purposes or use of satellites in orbit for commercial telecommunication services, which are two kinds of space activities encouraged by the freedom principle specified in Article I of the OST, both constitute a 'use' of outer space. ${ }^{9}$ However, they do not and can never constitute a 'national appropriation' that gives rise to territorial sovereignty. Likewise, no

7 S. Hobe, Article I, in Cologne Commentary on Space Law: Outer Space Treaty $§ 1$ 25-44 (S. Hobe, B. SchmidtTedd, Kai-Uwe Schrogl eds., 2009). (It has been asserted that, even before the adoption of the OST, it "was realized that by denying the legality of such [sovereignty] claims the interests of the world community as a whole would be best served.").

8 P. Martinez, et al., Reflections on the 50th Anniversary of the Outer Space Treaty, Unispace+50, and Prospects for the Future of Global Space Governance, 47 SPACE PoL'y 28-9 (2019).

9 Article I of the OST states that "[ $t$ ]he exploration and use of outer space, including the moon and other celestial bodies, shall be carried out for the benefit and in the interests of all countries, irrespective of their degree of economic or scientific development, and shall be the province of all mankind. Outer space, including the moon and other celestial bodies, shall be free for exploration and use by all States without discrimination of any kind, on a basis of equality and in accordance with international law, and there shall be free access to all areas of celestial bodies. There shall be freedom of scientific investigation in outer space, including the moon and other celestial bodies, and States shall facilitate and encourage international co-operation in such investigation." 
'occupation' of outer space can constitute a "national appropriation" that leads to territorial sovereignty. Under classical international law, a state is eligible for claiming a legitimate legal interest in a terra nullius through 'occupation' or 'prescription', provided that it meets certain legal conditions such as continuous and peaceful effective control over that territory. ${ }^{10}$ These modes of territorial possession do not apply to outer space, where is an area of res communis omnium. By prohibiting claims of territorial sovereignty in outer space or any of its parts based on occupation, Article II of the OST confirms that traditional international laws that permit the acquisition of territorial sovereignty over 'non-owned' lands, such as through discovery, occupation and effective possession, do not apply to outer space. ${ }^{11}$

Prohibition of claims of territorial sovereignty includes claims from both States and private entitles. The history of the OST negotiation clearly illustrates that the majority of the delegates who had a part in the discussions believe that Article II prohibits both public and private appropriations. ${ }^{12}$ Some scholars also verify that private entities need not to be explicitly mentioned in Article II but are still subjected to the "non-appropriation" principle. It is because the OST did not create a dichotomy between governmental and non-governmental entities in this regard. Likewise, Jenks noted that "states bear international responsibility for national activities in space; it follows that what is forbidden to a state is not permitted to a chartered company created by a state or to one of its nationals acting as a private adventurer." ${ }^{, 13}$ In accordance with Article VI of the OST, private actors are permitted to undertake space activities but must be under the authorization of the proper state of nationality. ${ }^{14}$

However, if a state is prohibited from participating in some conduct, then it

10 R. Lesaffer, Argument from Roman Law in Current International Law: Occupation and Acquisitive Prescription, 16 EuR. J. INT'L L. 25-58 (2005).

11 For a discussion of various modes of territorial acquisition, see M. SHAW, InTERNATIONAL LAW 495-507 (5th ed. 2004).

12 D. Goedhuis, Legal Aspects of the Utilization of Outer Space, 17 Neth. InT'L L. Rev. 36 (1970). (According to Goedhuis, "a study of the preparatory work of the [Outer Space] Treaty clearly shows that the draftsmen of the principle of non-appropriation never intended this principle to be circumvented by allowing private entities to appropriate areas of the Moon and other celestial bodies.")

13 P. Sterns \& L. Tennen, Privateering and Profiteering on the Moon and Other Celestial Bodies: Debunking the Myth of Property Rights in Space, 31(11) Advances In Space Res. 2436 (2003). See also C. Jenks, Space Law, 14 Int'L \& Comp. L. Q. 201 (1965).

14 M. Gerhard, Article VI, in Cologne Commentary On Space Law: Outer Space Treaty, supra note 7, at 103-25. (Article VI of the OST provides that: "States Parties to the Treaty shall bear international responsibility for national activities in outer space, including the Moon and other celestial bodies, whether such activities are carried out by governmental agencies or by non-governmental entities, and for assuring that national activities are carried out in conformity with the provisions set forth in the present Treaty. The activities of non-governmental entities in outer space, including the Moon and other celestial bodies, shall require authorization and continuing supervision by the appropriate State Party to the Treaty.") 
lacks the authority to license its nationals or other entities under its jurisdiction to participate in that activity itself. ${ }^{15}$ Therefore, the non-appropriation principle in Article II of the OST should be read and understood as an all-inclusive principle, which permits the exclusion of private appropriation of outer space and any of its parts. Against this context, to explicitly specify "private appropriation" in the OST would have been redundant. ${ }^{16}$ Moreover, even if a state acknowledges the territorial acquisitions of any of its subjects such as private entities, this would constitute a form of national appropriation by "any other means," which remains in violation of Article II of the OST. This "catch-all" phrase can prevent a state from using other kinds of entities to conduct a related act of appropriation for its benefits. ${ }^{17}$ This vigilant and deliberate emphasis at the end of Article II leaves no room for any kind of appropriation of outer space by any means. Thus, while the OST does not specify the terms of private appropriation, it does not allow any state to admit or enforce a private claim. Should a state acknowledge, approve or protect in any way a territorial acquisition of any of its national subjects, this would amount to a "national appropriation" inconsistent within Article II of the OST. ${ }^{18}$

In summary, Article II together with Article VI of the OST jointly affirm that outer space cannot be appropriated by either state or non-governmental entities. Space activities carried out by any entity will never constitute a legitimate claim of territorial acquisition. Besides, Articles I and II of the OST constitute fundamental elements of the legal regime of outer space. All states have free access to outer space on an equal basis without discrimination. Consequently, they are free to explore and use outer space. However, states and their governing nationals cannot claim territorial sovereignty because outer space cannot legally be appropriated by any state. The primary intent of Article II was to strengthen the essential concepts in Article I in terms of safeguarding outer space from the potential conflict driven by territorial or colonization-driven ambitions. ${ }^{19}$ Since the start of space-age with launching Sputnik 1 in 1957 by the then Soviet Union, no State has raised any substantial objections

15 Supra note 13 , at 2437.

16 M. Markoff, A Further Answer Regarding the Non-Appropriation Principle, 13тн COLLoQuIUm ON THE LAW OF OUTER SPACE Proc. 84-6 (1970).

17 H. Keefe, Making the Final Frontier Feasible: A Critical Look at the Current Body of Outer Space Law, 11 SANTA Clara Comp. \& High Tech. L. J. 358 (1995).

18 The Board of Directors of the International Institute of Space Law (IISL) has addressed that the prohibition of national appropriation as established by Article II also includes appropriation by non-governmental entities (could be individuals or legal persons). See IISL, Statement by the Board of Directors of the IISL on Claims to Property Rights Regarding the Moon and Other Celestial Bodies (2004), available at http://www.iislweb.org/docs/IISL_Outer_Space_Treaty_ Statement.pdf.

19 Supra note 7 , at 27. 
that the orbiting of a space object impinges on their territorial sovereignty. As a result, the non-appropriation principle in Article II of the OST represents a rule of customary international law. ${ }^{20}$ Tronchetti even emphasized that this principle should be considered as a "structural rule of international law." 21 This principle not only represents a starting point of the approach followed by states in establishing the entire system of international space law, but also constitutes the basic rule that states are obliged to follow when operating in outer space to ensure the safe, orderly and peaceful development of space activities.

\section{B. Failed Claims of Territorial Sovereignty in Outer Space}

While the OST has indicated that outer space is not subject to appropriation and there is no claiming of territorial sovereignty in space, there has been such claims and practices that have taken place before and after the adoption of the OST. ${ }^{22}$ Three specific cases related to claims of territorial sovereignty in outer space by nongovernmental entities or states will be analyzed in this article, which are the Lunar Embassy, Nemitz vs. NASA and US, and the Bogotá Declaration, respectively.

\section{Lunar Embassy}

In recent, some private companies have started selling plots of land on the Moon. They have issued "deeds of sale" as evidence of ownership for the buyers who have bought these plots. A renowned company who is selling "extraterrestrial estate" is the Lunar Embassy, established in 1980 by Dennis Hope. ${ }^{23}$ Hope based his claims of owning the Moon on the fact that private individuals are not included in the prohibition of outer space appropriation as contained in Article II of the OST. His argument based on the interpretation of Article II has already been invalidated by the reasons discussed in Part II(A) of this paper. To support his cause, Hope also referred to the lack of response from the authorities in the US and other countries, to which he informed his claim of ownership over the Moon. Hope deduced the lack of objection to his claim as acceptance of the legitimacy of his argument and implicit approval

20 Z. Paliouras, The Non-Appropriation Principle: The Grundnormof International Space Law, 27 LeIDEN J. INT'L L. 37-54 (2014). See also A. Pershing, Interpreting the Outer Space Treaty's Non-Appropriation Principle: Customary International Law from 1967 to Today, 44 YALE J. INT'L L. 149-78 (2019).

21 F. Tronchetti, The Non-Appropriation Principle as a Structural Norm of International Law: A New Way of Interpreting Article II of the Outer Space Treaty, 33 AIR \& Space L. 277-305 (2008).

22 F. Tronchetti, The Exploitation of Natural Resources of the Moon and Other Celestial Bodies: A Proposal FOR A Legal Regime 203-4 (2009).

23 D. Hope, Lunar Embassy, available at http://lunarembassy.com. 
to claim ownership. However, his inference cannot be accepted under the existing rules of international law. As Blum suggested, "the absence of protest is relevant in the formation of a historic title only in those cases in which protest would have been expected to be forthcoming, had the affected state really whished its objection to be made known." ${ }^{24}$ It is evident that neither the US nor any other countries are obligated to respond to Hope. In essence, none of these authorities would have the power to recognize or refuse the lawfulness of the claim. Such a claim has no legal basis as the Moon is non-appropriable by any state or private entity. Therefore, the lack of objection by the relevant authorities should not be understood as approval of Hope's claim. By contrast, it should be perceived as further validation of its unlawfulness in general and infeasibility under international law.

In upholding his claim, Hope also resorted to the fact that he had registered his claim on the Moon at an US governmental office in accordance with the US domestic laws. He contended that his claim could not be rejected by international law because even though international and national laws constitute two different legal orders, when a state commits to specific international legislation, it is obligated to ensure that the national law complies with these international legislations. ${ }^{25}$ Except for the Agreement Governing the Activities of States on the Moon and Other Celestial Bodies (The Moon Agreement), the US has signed and ratified four of the five existing UN space law treaties. ${ }^{26}$ Since 1958 , the US has passed national space laws aiming to ensure that the execution and function of the rules at the national level were included in the space treaties. ${ }^{27}$ This clearly demonstrates that the provisions of the four UN space law treaties are fully applicable and enforceable within the US jurisdiction, and any federal acts that are inconsistent with such provisions must be considered inapplicable as well as invalid. In terms of Hope's case, it is therefore not sufficient for any 'owner' of property on the Moon or other celestial bodies to use national law to justify his/her claim. This point of view has also been maintained by the Board of Directors of the IISL that "the prohibition of national appropriation (...) precludes the

24 Y. Blum, Historic Titles in International Law 99-100 \& 130-1 (1965).

25 S. Beaulac, National Application of International Law: The Statutory Interpretation Perspective, 41 CAN. Y.B. INT'L L. 225-70 (2004).

26 The other four agreements are as follows: Outer Space Treaty; Agreement on the Rescue of Astronauts, the Return of Astronauts and the Return of Objects Launched into Outer Space (Rescue Agreement); Convention on International Liability for Damage Caused by Space Objects (Liability Convention); and Convention on Registration of Objects Launched into Outer Space (Registration Convention).

27 The United States has enacted inter alia the National Aeronautics and Space Act of 1958, as amended in 1983; the Land Remote-Sensing Commercialization Act of 1984; the Land Remote-Sensing Policy Act of 1992; the Commercial Space Act of 1998 . 
application of any legislation on a territorial basis to validate a private claim." 28

The illegitimacy of the activities undertaken by the Lunar Embassy has also been formally condemned by a court judgment. The Lunar Embassy has incorporated its daughter companies to appoint ambassadors around the world. In October 2005, Beijing industrial and commercial authorities suspended the license of the Lunar Embassy in China because they claimed that the Lunar Embassy was involved in speculation, fraud and profiteering. The Lunar Embassy was fined RMB 50,000. The Lunar Embassy in China responded to sue the relevant authorities in Beijing to express its disappointment towards the accusations. ${ }^{29}$ As the Haidian District People's Court ruled against the company in November 2005, the Lunar Embassy further took action to appeal the court's decision. In March 2007, the Beijing First Intermediate People's Court upheld the original judgment by stating that neither State nor individual can claim ownership of the Moon. ${ }^{30}$ In its ruling, the court alluded to the fact that China has been a state member of the OST since 1983, and certainly prohibits the appropriation of outer space or any of its parts. The verdict of the Chinese court is an essential means of confirmation of the non-appropriative nature of outer space, and any private ownership claims that strive to be legally recognized as having territorial sovereignty over the Moon and other celestial bodies are null and void.

\section{Nemitz vs. NASA and the US}

An American citizen Gregory Nemitz registered his claim to Asteroid 433 Eros in 2003, which was published by the Archimedes Institute. When NASA landed an aircraft on his property, Nemitz invoiced them for rent and parking. ${ }^{31}$ NASA did not pay, and their lawyer responded to Nemitz in a letter which stated:

Your individual appropriation of a celestial body (the asteroid 433 Eros) appears to have no foundation in law. It is unlike an individual's claim for seabed minerals, which was considered and debated by the US Congress that subsequently enacted a statute, the Deep Seabed Hard Mineral Resource Act [...] expressly authorizing such claims. There is no similar statute related in outer space. Accordingly, your request for payment of a parking/storage fee is denied, ${ }^{32}$

28 Supra note 18.

29 See Beijing Authorities Suspend License of 'Lunar Embassy', People.com, Nov. 7, 2005, available at http://en.people. cn/200511/07/eng20051107_219609.html.

30 See Court Rejects Lunar Embassy's Right of Moon Land Selling, ChInA.org.CN (Mar. 17, 2007), available at http:// english.china.org.cn/english/China/203329.htm.

31 Letter from Edward Frankle, General Counsel, NASA Commercial and International Law Division to Gregory Nemitz, Chief Execultive Officer, NASA Orbital Development (Apr. 9, 2001), available at http://orbdev.com/010409.html. 
Nemtiz then proceeded to file a suit against them in the federal court, arguing that the US had utilized his property without fair compensation. The government filed a motion to dismiss, which were subsequently granted by the Federal District Court for the District of Nevada. The court noted that Nemitz did not manage to support his property rights, so there was no basis for compensation. The court also ruled that neither the failure to the US to ratify the [...] Moon Treaty, nor the US's ratification in 1967 of the OST, created any rights in Nemitz to appropriate property rights on asteroids. Nemitz appealed the case to the Ninth Circuit Court of Appeals, who however maintained the previous verdict and ultimately dismissed the case. ${ }^{33}$ The reason is properly summarized in an opinion given by Ralph L. Braibanti, who was the Director of Space and Advanced Technology in the Department of State's Bureau of Oceans and International Environmental and Scientific Affairs. In an analogous response as that of the NASA lawyer, he responded to Nemitz's claim that “... private ownership of an asteroid is precluded by Article II [...]. Accordingly, we have concluded that your claim is without legal basis."34 The Nemitz case represents yet another example of the rejection of extraterrestrial private property rights that had been legally recognized. Two US courts ruled against the permissibility of private ownership claims over a celestial body.

\section{Bogotá Declaration}

The Declaration of the First Meeting of Equatorial Countries (Bogotá Declaration) in 1976 is also a well-known example that illustrates the non-appropriation principle in Article II of the OST. ${ }^{35}$ Developing countries were concerned that the geostationary orbits occupied by the developed countries could prevent them from using orbit/ spectrum resources in the future. These concerns were publicly reflected in the 1976 Bogotá Declaration. ${ }^{36}$ In this Declaration, some of the equatorial developing countries claimed sovereignty rights over the parts of the geostationary orbit ("GSO") that laid over their respective territories. Thus, any placement of satellites in this orbit would require their authorization and some compensation would be necessary. ${ }^{37}$

33 The Eros Project for Space Property Law, Eros Project, available at http://www.erosproject.com.

34 K. Zullo, The Need to Clarify the Status of Property Rights in International Space Law, 90 Geo. L. J. $2413-44$ (2002).

35 Declaration of the First Meeting of Equatorial Countries (Bogota Declaration) (adopted on Dec. 3, 1976), reprinted in N. Jasentuliyana \& R. Lee, Manual on Space Law 383 (1981). For an analysis of the Bogota Declaration and the Geostationary Orbit, see F. Agama, Effects of the Bogota Declaration on the Legal Status of Geostationary Orbit in International Space Law, 8 NAmDi AzIKIwE U. J. INT’L L. \& Juris. 22-34 (2017).

36 See Declaration of the First Meeting of Equatorial Countries of Dec. 3, 1976, ITU DOC. WARC-BS-81-E. The eight equatorial States were: Brazil, Colombia, Congo, Ecuador, Kenya, Indonesia, Uganda and Zaire.

37 Declaration of the First Meeting of Equatorial Countries, art. 3 (literal e). 
One of the rationales justifying the terms in the Bogotá Declaration was that the existence and the distinctive characteristics of the GSO depend on the relation of gravitational forces to Earth. If considering the GSO as a non-part of outer space, the GSO is therefore part of the national territory. Given that each nation is entitled to control its own natural resources, the equatorial States contended that sections of the GSO belonged to the nations that have territory directly underneath these sections. However, the argument was considered weak as gravitation is not generated only by the equatorial States and gravitation forces on the Earth control every orbit. The declarants also referred to Part 4 of the Declaration, where they emphasized that the OST did not indicate the commencement of outer space and this was also not addressed through a consensus by the United Nations Committee on the Peaceful Use of Outer Space ("UNCOPUOS"). Nevertheless, after the launching of the first satellites or throughout the continuous use of the geostationary orbit after 1963, there had been no official objections on the violation of sovereignty rights until the Bogotá Declaration.

While the Bogotá Declaration had some support from other equatorial nations, ${ }^{38}$ it was ultimately rejected by both developed and developing countries. Spacefaring states indicated that the arguments made by the declarants did not have enough grounds to allow them to enforce their claims physically. Conversely, other developing countries who did not have an equatorial position indicated that the arguments in the Bogotá Declaration were limited and arbitrary. ${ }^{39}$ Moreover, the request for (territorial) sovereignty over parts of the GSO contravenes the nonappropriation principle in Article II of the 1967 OST as the GSO belongs to outer space and is therefore not subject to any governmental or state sovereignty. ${ }^{40}$ Therefore, the Bogotá Declaration was unsuccessful and the intended goals were not realized. As noted by Freeland and Jakhu, "what came to light in this Declaration however, was the aspiration of developing states of being granted some participatory rights with regard to outer space activities." ${ }^{41}$ Indeed, the failure of the Bogotá Declaration served to reinforce the legality of the non-appropriation principle outlined in Article II of the OST.

To summarize, both treaty interpretations and consistent legal actions taken by the

\footnotetext{
38 For instance, the Gabon Republic and the Somali Democratic Republic supported the Bogotá declarants' arguments in many occasions. See WARC on Broadcasting Satellite of the International Telecommunications Union (Feb. 13, 1977), WARC BS-77, at 51 .

39 See "Geostationary satellite orbit" Working Paper, U.N. Doc. A/AC.105/C.2/L.192 (Mar. 30, 1993).

40 S. Freeland \& R. Jakhu, Article II, in Cologne Commentary on Space Law: Outer Space Treaty, supra note 8, at 44-62.

41 Id.
} 
appropriate administrative and judicial bodies in the three cases clearly indicate that any claim of territorial sovereignty in outer space by any means is incompatible with Article II of the OST. The outer space, which comprises the Moon and other celestial bodies, is not appropriable by both states and non-governmental entities alike. All of the arguments for territorial sovereignty over the Moon and other celestial bodies are ultimately rejected because there are no grounds under the existing space law. The general consensus on the binding value of the non-appropriation principle in Article II of the OST leads to the principle a rule of customary international law. ${ }^{42}$

\section{Territoriality Principle under the IP Legal Regime}

In international law, the fundamental jurisdictional principle consists of territoriality, which means that a national government has legislative or prescriptive competence within the geographic scope of its territory. ${ }^{43}$ The territoriality principle stems from the principle of public international law, which has gained mutual acceptance among nations. It means that if incidents take place within the borders of a nation, these fall into its exercise of jurisdiction, while if any incident takes place beyond the borders of a nation, this nation has no jurisdiction over it. This also applies to individuals, as pointed out by Hammerle and Ro that "the territorial jurisdiction of a national court over a person or a case or controversy concerning an activity typically has its limits defined by the geographical boundaries of the territory to which a particular person resides or an activity originates." ${ }^{\prime 4}$ This is also the case for IPRs, which is no exception to general international law and by their very nature. IPRs are restricted locally to the territory of the state in which it was granted. In principle, IPRs have no extraterritorial effects. $^{45}$

42 Supra note 20.

43 I. Brownlie, Principles of Public International Law 298-308 (6th ed. 2003). Brownlie reviews six bases for criminal jurisdiction in particular. He then notes that there are no important differences between criminal and civil jurisdiction with respect to extraterritorial application of a state's law: (a) The territorial principle; (b) The nationality principle; (c) The passive personality principle; (d) The protective or security principle; (e) The universality principle; and (f) Crimes under international law.

44 K. Hammerle \& T. Ro, The Extra-Territorial Reach of US Patent Law on Space-Related Activities: Does the International Shoe Fit as We Reach for the Stars, 34 J. SPACE L. 241 (2008).

45 C. Bradley, Territorial Intellectual Property Rights in an Age of Globalism, 37 VA. J. InT'L L. 505-86 (1996). 


\section{A. Evolving Paradigms of IPRs Protection}

The historical evolution of IPRs protection is generally considered to have taken place in three broad phases: national, international, and global levels. ${ }^{46}$ One of the major characteristics of IPRs is that they are national or territorial in nature, which is also the well-known "principle of territoriality." As Mosteshar pointed out, "by their very nature IPRs are jurisdictional both in terms of their recognition and existence and the protection that may be afforded to the owner of such rights." ${ }^{47}$ Pursuant to this principle, the IPRs obtained in a state generally do not have legal effects beyond their national borders.

\section{National Protection of IPRs}

Before the end of the nineteenth century, the protection of IPRs was strictly a matter of each individual State. Not only did the individual States endorse their own IP laws based on their own needs, but also the protection offered by these laws did not cross national borders. Given that "patents are granted by national governments, they are inherently territorial and may only be enforced within the jurisdiction of the granting government. The holder of a U.S. patent, for example, may only enforce the patent against someone who makes, uses, or sells the patented invention within the United States. ${ }^{48}$ For this reason, an inventor must file an independent patent application in each country where s/he/they intend to obtain exclusive rights to an invention.

The territoriality principle is not always so straightforward, especially when transnational activities are taken into consideration. First, public international law allows for the extension of the application of national laws to physical objects which are beyond their actual area of territorial application but just passing through other nations, such as ships that travel on territorial seas, artificial installations on the continental shelf, aircraft that pass through territorial areas and so on. ${ }^{49}$ Second, IPRs may be extra-territorially enforceable so long as the granting state exercises

46 P. Drahos, Thinking Strategically About Intellectual Property Rights, 21 Telecomm. PoL'y 201-11 (1997). See also A. Anderson \& B. Razavi, The Globalization of Intellectual Property Rights: TRIPS, BITs, and the Search for Uniform Protection, 38 GA. J. INT'L \& Comp. L. 265-92 (2010); R. Epstein, The International Evolution of Intellectual Property Rights, 5 NYU J. Intell. Prop. \& Envtl. L. 107-12 (2015).

47 S. Mosteshar (eds.), Research and Invention in Outer Space: Liability and Intellectual Property Rights 134 (1995).

4835 U.S.C. § 271(a). The US Patent Act defines patent infringement as follows: "Except as otherwise provided in this title, whoever without authority makes, uses, offers to sell, or sells any patented invention, within the United States, or imports into the United States any patented invention during the term of the patent therefor, infringes the patent."

49 A. Colangelo, What Is Extraterritorial Jurisdiction, 99 Connell L. Rev. 1303-52 (2014). See also K. Zalucki, Extraterritorial Jurisdiction in International Law, 17 InT'L Comm. L. Rev. 403-12 (2015). 
jurisdiction on some other basis. ${ }^{50}$ Extraterritorial jurisdiction is the limited extension of the territorial authority of a nation and its courts. A national court may exercise extraterritorial jurisdiction in other countries via a treaty or through the ministers or consuls of a nation in another country. Extraterritorial jurisdiction of a national court should be based at least in part on a nexus between the territory of the forum and the person or the activity to which the court is now interested in seeking to exercise such broader authority. This is called the "effects doctrine."

The effects doctrine, whereby a nation asserts prescriptive jurisdiction over extraterritorial activities thus causing a significant effect within the nation's territory, appears to change the territoriality doctrine. However, the effects doctrine is not a real departure from the territoriality doctrine, since it governs extraterritorial conducts that are related to significant intra-territorial effects. Thus, the effects doctrine departs from the limited territorial legitimacy of the exercise of a sovereign's prescriptive power and yet simultaneously reinforces this legitimacy. ${ }^{52}$ The IPRs do not typically purport to prescribe extraterritorial conduct. ${ }^{53}$ In its roots, the territoriality principle remains the setting of international lawmaking and dispute resolutions.

\section{International Protection of IPRs}

Along with the increased expansion of international business, the domestic protection of IPRs does not meet the resultant needs. Accordingly, the territoriality principle of the IPRs, under the context of international trade, has long been a point of contention for the copyrights, inventions, and trademarks of IPRs owners. Thanks to the extensive international cultural and economic exchanges throughout the nineteenth century, it was found that IPRs protection at the national level is not sufficiently effective enough and the IP legal regime needed improvement. This was especially the case for countries who were net exporters of IPRs. Therefore, they started to seek solutions to safeguard the rights of their authors, designers, inventors, and trademark owners in other countries. ${ }^{54}$

50 M. Boulware, et. al., An Overview of Intellectual Property Rights Abroad, 16 Hous. J. INT'L L. 441-508 (1994). See also M. Trimble, Extraterritorial Intellectual Property Enforcement in the European Union, 18 Sw. J. INT'L L. 233-44 (2011).

51 S. Metzger, The "Effects" Doctrine of Jurisdiction, 61 Am. J. InT'L L. 1015-18 (1967). See also J. Coppel, A Hard Look at the Effects Doctrine of Jurisdiction in Public International Law, 6 LEIDEN J. INT'L L. 73-90 (1993).

52 H. Maier (eds.), Extraterritorial Jurisdiction in Theory and Practice 64-102 (1996).

53 R. Dreyfuss, et. al., Intellectual Property: Principles Governing Jurisdiction, Choice of Law, and Judgments in Transnational Disputes (2008).

54 H. He, The Development of Free Trade Agreements and International Protection of Intellectual Property Rights in the WTO Era - New Bilateralism and Its Future, 41 IIC-Int'L Rev. Intell. Prop. \& Competiton L. 253-83 (2010). 
In the beginning, a number of bilateral treaties were signed by two countries to provide IPRs protection to the nationals of the other. At the end of the nineteenth century, two international IP conventions, namely the Paris Convention for the Protection of Industrial Property (hereinafter Paris Convention) and the Berne Convention for the Protection of Literary and Artistic Works (hereinafter Berne Convention), were adopted based on the principle of national treatment. It is worth noting that the principle of national treatment is fundamentally a rule of nondiscrimination and well manifests the territorial nature of the IP legal regime. The principle not only gives countries the autonomy to develop and enforce their own domestic laws, but also requires them to comply with the requirements of international protection. The Paris Convention and the Berne Convention govern international IPRs protection without harmonization. States retained substantial regulatory autonomy in developing their laws in line with their own domestic economic development and comparative advantages in either innovation or imitation. Differences in scope and duration of protection were so permitted. ${ }^{55}$

Even though the level of IPRs protection shifted from the domestic to the international level, the basis of the Paras Convention and the Berne Convention remained set on the principle of territoriality. ${ }^{56}$ The scope of IPRs application was bound by the laws of the country in which protection had been sought. By acquiring and upholding equivalent foreign rights on this basis, right owners may attain a certain level of international protection for their IP. Therefore, international IP conventions guaranteed national treatment and a minimum standard of IPRs protection, and provided various mechanisms by which rights may be acquired in foreign states. Despite this internationalization of standards, IPRs remained virtually domestic rights. IPRs were "granted unilaterally by governments of individual states. Although multilateral treaties have achieved a measure of universality for domestic protection standards, the international community has yet to achieve universality of enforcement. ${ }^{, 57}$ The procedures for granting IPRs and the nature of the exclusive rights that are granted could widely vary from country to country, thereby rendering the international application and enforcement of patents a financial and administrative burden. ${ }^{58}$

55 Berne Convention art. 5.2 \& TRIPS art. 9.1.

56 Supra note 46, at 202.

57 C. DeCluitt, International Patent Prosecution, Litigation and Enforcement, 5 Tulsa J. ComP. \& INT'L L. 144-6 (1997).

58 G. Dutfield \& U. Suthersanen, Global Intellectual Property Law 22-42 (2008). 


\section{Global Protection of IPRs}

Albeit that the principle of national treatment offers IPRs owners with a certain level of international protection in other jurisdictions, its effect was not sufficient enough. The principle of national treatment failed to address one essential procedural issue of registration. For instance, if one country deemed registration as a prerequisite for IPRs protection, then the nationals of other countries who seek IPRs protection in this country have to register first. The procedure was time-consuming and costly. In removing the inefficiency caused by registration, the international community had to put forth extraordinary effort at the end of the nineteenth century. In terms of copyright, this was achieved by requiring members of the Berne Union to grant copyright protection without the need for formalities (such as registration). In trademarks, a mechanism was developed whereby a national trademark owner could make an "international registration," which would take effect almost immediately in the designated countries. ${ }^{59}$ However, a similar procedure for international applications of patents was not developed until 1970 when the Patent Co-operation Treaty entered into force. As regards the industrial design, the deposit of a single design application would be recognized throughout all countries that are signatories to The Hague Agreement concerning the International Deposit of Industrial Designs of 1952.

The Agreement on Trade-Related Aspects of Intellectual Property Rights ("TRIPS") officially created a new era in the evolution of IPRs. It did not construct a uniform protection of IPRs among the member States, but rather harmonized IPR protection at the national level. In considering that the different IP regimes bring significant impediments to international trade, the TRIPs thus sought to offset the drawbacks of the territoriality principle and improve the overseas legal position of IPRs holders by providing a minimum level of harmonization. For the most part, it required the WTO members to recognize the existing standards of protection within the Berne Convention and the Paris Convention. Moreover, the TRIPS covered a wide range of significant IP categories. ${ }^{60}$ Substantive protection for rights such as neighboring copyright, trademarks, geographical indications, designs, patents, topographies of integrated circuits and undisclosed information are included in the TRIPS. Overall, the conclusion of international treaties on the protection of IPRs follows the principle

59 The Madrid Agreement concerning the International Registration of Marks 1891. (However, given that trade mark procedures remained a matter for national law, this system proved unattractive to some countries, including the UK).

60 D. Gervais, The trips Agreement: Drafting History and Analysis (2d ed. 2003). See also M. Spence, Which Intellectual Property Rights Are Trade-Related?, in Environment, Human Rights \& International Trade 279-80 (F. Francioni ed., 2001). 
of territoriality by integrating the provisions of national treatment. The TRIPS reinforces this principle to a great extent as the principle of Most-Favoured-Nation Treatment ("MFN") treatment was further integrated into the agreement.

\section{B. Territoriality Principle Derived from the IP Treaties}

The principle of national treatment was a common feature in the pre-TRIPS international treaties with respect to IPRs. It essentially protects against discrimination of foreigners vis-a-vis nationals. This means that each contracting member should accord to the nationals of the other members no less favorable treatment than it accords to its own nationals. In the opinion of the Appellate Body of the WTO, national treatment had been the cornerstone of the Paris Convention and other intellectual property conventions. ${ }^{61}$ In the beginning of the IPRs international regime, countries principally endeavored to prevent discrimination against their nationals. This objective was pursued in the Paris Convention and acknowledged by some other IPRs international treaties later. More specifically, the pre-TRIPS conventions mandated that foreigners should be given the same treatment as nationals, such kinds of regulation in national treatment are well reflected in Article 2(1) the Paris Convention, Article 5 (1) of the Berne Convention, and Article 3(1) of the TRIPS. ${ }^{62}$

The TRIPS also required members to apply the MFN principle which is traditionally reserved to trade in goods and services. In accordance with the MFN principle the outlined in Article IV of the TRIPs, "any advantage, favor, privilege or immunity granted by a Member to the nationals of any other country shall be accorded immediately and unconditionally to the nationals of all other Members." It should be noted that the principle of the MFN applies in relation to benefits accorded to nationals of "any other country." Hence, the WTO members should be accorded with the MFN treatment when benefits are granted to them. As incorporated, the MFN principle aims to ensure that all WTO members receive the same favor granted by a country to any other member within the WTO. This principle was absent in the

61 H. Andersen, Protection of Non-Trade Values in WTO Appellate Body Jurisprudence: Exceptions, Economic Arguments, and Eluding Questions, 18 J. INT'L ECON. L. 383-405 (2015).

62 Article 2(1) of the Paris Convention states that: "Nationals of any country of the Union shall, as regards the protection of industrial property, enjoy in all the other countries of the Union the advantages that their respective laws now grant, or may hereafter grant, to nationals; all without prejudice to the rights specially provided for by this Convention ...."; Article 5 (1) of the Berne Convention states that: "Authors shall enjoy, in respect of works for which they are protected under this Convention, in countries of the Union other than the country of origin, the rights which their respective laws do now or may hereafter grant to their nationals, as well as the rights specially granted by this Convention."; Article 3(1) of the TRIPS states that: "Each Member shall accord to the nationals of other Members treatment no less favorable than that it accords to its own nationals with regard to the protection of intellectual property, subject to the exceptions ..." 
pre-TRIPS international conventions and indicated the motivation of the negotiating parties of the GATT to firmly integrate the TRIPS disciplines into a multilateral trading system. ${ }^{63}$ This intention was explicitly acknowledged by the Appellate Body that "there is no provision in the Paris Convention (1967) that establishes a mostfavored-nation obligation with respect to rights in trademarks or other industrial property. However, the framers of the TRIPS decided to extend the most-favorednation obligation to the protection of intellectual property rights covered by that Agreement." ${ }^{, 64}$

In summary, the territoriality principle has long been the basis of prescriptive jurisdiction in IP for most nations. It means that IPRs are territorial in nature and generally null once national borders are crossed. The Berne Convention, the Paris Convention and the TRIPS are adopted on the basis of the territoriality principle. Even though the IP legal regime has witnessed a shift from the domestic to the international level and temporally reached acknowledgment at the global level, the internationalization and global harmonization of IPRs continue to follow the principle of territoriality by means of subjecting to the principles of national treatment and MFN under the WTO rules. The term "national/nation" points to the nature of the territorial sovereignty on which the world trade regime has been established, including that of IPRs. Accordingly, the provisions in the Paris Convention, the Berne Convention and the TRIPS are generally applied in such a way that the law of the nation in which the unauthorized use of IP has occurred is the law used to determine the existence of protection for the IP as well as the infringement nature of the unauthorized use. ${ }^{65}$ It can be concluded that the principle of territoriality has been a constant presence despite the continuous evolution that has taken place in the IP legal regime.

\section{The Regulatory Approach to Reconcile the Paradox}

In Parts II and III, the theoretical territoriality paradox is unveiled by comparing intrinsic features of legal regimes between outer space and IP. Such a theoretical clash

63 E. Crowne, Fishing TRIPS: A Look at the History of the Agreement on Trade-Related Aspects of Intellectual Property, 2 Creighton InT'L \& Comp. L. J. 77-110 (2011).

64 Appellate Body Report, US-Havana Club Case, $\uparrow 297$ WTO Doc. WT/DS160/AB/R (adopted June 15, 2005).

65 G. Austin, Domestic Laws and Foreign Rights: Choice of Law in Transnational Copyright Infringement Litigation, 23 Colum. J. L. \& ARTs 24-5 (1999). 
of values leads to the worry that the outer space legal regime theoretically precludes the IP legal regime. This leads to existing legal status that neither the international treaties of IP explicitly consider in their provisions the issue of IPRs protection in outer space, nor the provisions of the five outer space treaties notably address IP issue. Not to mention the obstacles that such theoretical conflict would have brought for the legal harmonization of an international treaty for IP protection in outer space in the future. This kind of legal status may substantially discourage States and nongovernmental entities from actively engaging in space activities and is not beneficial for the commercial development of space industries. Nevertheless, Part IV moves further to argue that the theoretical territoriality paradox is proved to be a problem purely in legal theory and can be well addressed in legal practice. This is because the legal value of Article VIII of the OST elaborately reconciles the theoretical conflict and offers a self-contained mechanism that would enable guaranteed levels of IPRs protection in outer space. ${ }^{66}$

Given that no legal provisions can be found from the existing treaties under space law and IP law which explicitly concerns the issue of IPRs protection in outer space, it is worth investigating whether to establish a connection with the legal provisions of space law is possible in relation to the extension of existing legal regimes to space activities. For instance, if the extension of domestic IP law can be made, this would also amount to the determination of which state's IPRs are applicable against the acts of IP conferment and infringement. In fact, Article VIII of the OST does provide a selfcontained mechanism that allows the implicit application of IPRs in outer space. ${ }^{67}$

Article VIII of the OST introduces the mode of "quasi-territorial" jurisdiction in international law to outer space, which indeed grants functional sovereignty for States. Functional sovereignty permits States to have 'ownership' of space objects, which are movable property, in a legal sense for a limited functional purpose. On this ground, even in the area outside any State, the appropriate State retains its sovereignty over the related space activities in an independent and maximum competence. Objects and personnel transported from Earth into outer space do not pass into a legal vacuum during their sojourn in the extraterrestrial area, but

\footnotetext{
66 Article VIII of the OST states: "A State Party to the Treaty on whose registry an object launched into outer space is carried shall retain jurisdiction and control over such object, and over any personnel thereof, while in outer space or on a celestial body. Ownership of objects launched into outer space, including objects landed or constructed on a celestial body, and of their component parts, is not affected by their presence in outer space or on a celestial body or by their return to the Earth. Such objects or component parts found beyond the limits of the State Party to the Treaty on whose registry they are carried shall be returned to that State Party, which shall, upon request, furnish identifying data prior to their return."

67 Supra note 5.
} 
continue in a legal relationship with the Earth. This legal relationship is connected by registration. Registration generates in the outer space a critical connection among the launching State, the space object, the international responsibility for space activities, as well as the jurisdiction and control by the state of registry. ${ }^{68}$ Jurisdiction and control over a space object can only be implemented by one of the launching States, namely, the one that has registered the object. This approach, which centres on a single state, allows the identification of a relevant domestic law applicable to the space object in question.

Since property right is a legal concept that is established under sovereignty, Article VIII of the OST also provides avenues for claiming functional property rights in outer space, including movable property as well as intangible IPRs. The provision identifies that some potential property objects launched into outer space, including those that have landed or are constructed on a celestial body, is not affected by their presence in outer space or on a celestial body. The jurisdiction applies to registered space objects, the reasonable area around the objects, and all of the personnel in or near the objects regardless of their nationality. Article VIII of the OST allows the State of registry to subject any personnel in the objects to its domestic laws as long as they do not conflict with international obligations. That means the restricted continuance of domestic law in space through the legal concept of "jurisdiction and control" was given consent in the OST, since it is necessary to maintain the order under public international law even in the extraterrestrial area. ${ }^{69}$ States are therefore entitled to regulate a wide range of public and private space activities in accordance with Article VIII of the OST. Without such a jurisdictional feature, a State would be unlikely to achieve the recognition of a wide range of rights from domestic laws. Thus, the application of domestic laws by a granting State over space activities carried out on a space object registered on its registry is a legitimate exercise of functional sovereignty under international law.

To this extent, the exercise of the State's functional sovereignty in outer space also covers the area of IP law. The State of registry, which retains jurisdiction and control over the objects and personnel transported into space, is empowered under public international law to determine which principles of IP law are valid on board of the space object that has been launched by this State. ${ }^{70}$ As Zhao Yun points

\footnotetext{
68 B. Schmidt-Tedd \& S. Mick, Article VIII, in Cologne Commentary on Space Law: Outer Space Treaty, supra note 7 , at $146-68$.

69 K. Bockstiegel et al., Patent Protection for the Operation of Telecommunication Satellite Systems in Outer Space, 47 ZLW 14 (1998).

70 S. Mosteshar, Issues Arising in Determining the Legal Regime Applicable to Intellecture Property Rights in Outer Space, in Research and Invention in Outer Space, Liability and Intellectual Property Rights 133-8 (S. Mosteshar
} 
out, jurisdiction and control serve as a link or connection to determine which IP law is applicable on space objects, or to regulate IPRs obtainment as well as IPRs infringement in a context that involves space activities. ${ }^{71}$ Under these circumstances, the applicability of domestic IP law in this area may be explicitly mandated and automatically implemented, as it has been done, for example, by the US in its IP law of Inventions in Outer Space Act of 1990 and the International Space Station Intergovernmental Agreement in $1998 .^{72}$ China has also made great efforts in IP protection in terms of enacting quite a few laws and regulations which can directly apply to the results obtained from space activities. ${ }^{73}$ The jurisdiction and control in space law can be thus defined that in terms of public international law, the State of registry is permitted to exercise its functional IPRs in outer space. ${ }^{74}$ Therefore, Article VIII of the OST permits the IPRs protection in practice, which actually well bypasses the public-private conflict in theory.

\section{Conclusion}

The regulatory environment of outer space has substantially changed into the era of space commercialization. The dilemma of the commercial development of space without explicit IPRs protection provisions in legal regimes of both outer space and IP has caused certain levels of interference to the active participation of some nongovernmental entities in space industries. One significant reason that has been given to explain the contributing factor to such legal status is the theoretical territoriality paradox between legal regimes of outer space and IP. A thorough examination that jointly combines legal interpretation and case analysis carried out in this article jointly uphold that the non-appropriation principle in Article II of the OST, as the fundamental principle of space law as well as a rule of customary international law, rejects claims of territorial sovereignty in outer space made by either States or nongovernmental entities. Any claims for the existence of territorial sovereignty should be rejected based on a lack of legality under the current space law framework. The

ed., 1995).

71 Y. Zhao, Intellectual Property Protection in Outer Space: Reconciling Territoriality of Intellectual Property with NonTerritoriality in Outer Space, 7 QueEn Mary J. Intell. Prop. 137-38 (2017).

72 Supra note 44, at 261-5.

73 Y. Zhao, National Space Law in China: An Overview Of The Current Situation and Outlook For The Future 198204 (2015).

74 P. Larsen \& F. Lyall, Space Law: A Treatise 127 (2013). 
prohibited territorial sovereignty nature of outer space, as validated by Article II of the OST, stands however in contrast to the fundamental territoriality principle of IP law. Aside from national IP legislation, international IP treaties are also rigorously subjected to the territoriality principle. Whereas IPRs have been continuously evolving towards the goal of global harmonization, the territorial nature of IP legal regimes remains unchanged. Thus, the theoretical territoriality paradox is one dominant conflict between the legal frameworks of outer space and IP.

Despite that there exists one theoretical territoriality paradox, it does not necessarily mean that the outer space laws preclude the IP laws, which would ultimately render the IP protection in outer space impossible in practice. In this article, the author would further argue that Article VIII of the OST itself provides a self-contained mechanism that permits the existence of functional IPRs in outer space. This mechanism uses space objects as a connecting factor to link space activities with the existing laws of the State of registry in order to realize functional sovereignty. Therefore, Article VIII of the OST provides a solid legal foundation for space legislation by individual countries. IPRs stemming from space activities carried out in space objects remain legally protected through the extension of existing IPRs of the State of registry to its space objects in outer space. In conclusion, the theoretical territoriality paradox between legal regimes of outer space and IP is a problem existing purely in legal theory and is well reconciled in legal practice. There is no real clash of values between the two legal regimes, as the legal value of Article VIII of the OST offers a regulatory approach for the IPRs protection in outer space and elaborately reconciles the theoretical conflict. 